\title{
The Contribution of EUROPOL and FRONTEX in Combating the Phenomenon of Illegal Immigration in Hellas
}

\author{
Korontzis Tryfon \\ Panteion University of Social and Political Sciences of Athens \\ P.Ralli 228, 18454, Nikaia, Piraeus, Greece \\ E-mail: tmkoront@otenet.gr
}

Received: October 30, 2011

Accepted: December 19, 2011

Published: March 1, 2012

doi:10.5539/res.v4n1p188

URL: http://dx.doi.org/10.5539/res.v4n1p188

The main points of this study were presented by me in a paper entitled «Surveillance of The Hellenic sea borders and trafficking of illegal immigrants. European policy, Frontex and the institutional role of the Hellenic Coast Guard», which was developed in the conference entitled "Immigration Policy: International trends and problems in modern Hellas», which was held on 14-15 May 2011 in Zaros, Crete/Hellas, by the Department of Political Science of the University of Crete /Association of postgraduate students.

\begin{abstract}
The rise in the phenomenon of illegal immigrants entry in the European area, led the Member - States (MS) of the European Union (EU) to develop policies as well as to establish services/agencies for their implementation, aiming to optimize the management of this phenomenon. The main European agents which are responsible to a large extent for the implementation of European policies in combating this phenomenon are the European Police Office (EUROPOL) and the European Agency for the Management of Operational Cooperation at the External Borders of the MS of EU (FRONTEX). The responsibilities of these two European institutions and the main action assistance that develop - provide to Hellas in order to tackle the illegal immigration in Europe will be the subject of this brief study. The study will also show that the co - ordination-cooperation of the Law Enforcement Agencies (LEAs) with the European Police Services/Agencies is imperative, as the phenomenon of illegal immigration concerns all the EU, and only through a holistic approach and action will positive results for all the MS occur.
\end{abstract}

Keywords: EUROPOL, FRONTEX, Illegal immigration, Hellas, Hellenic police, Hellenic coast guard, Law Enforcement Agencies (LEAs)

\section{Introduction}

In the last years there has been an increase in the emphasis in combating the trafficking of illegal immigrants, an issue which is a priority not only at national but also at European level. Migration is a phenomenon with specific causes, such as the widening of social and economic inequalities, civil wars, climate changes, environmental disasters, etc. Considering the fact that the EU generally is consisted by MS which most of them are characterized by economic prosperity and political stability, the reasons are understood why EU is a destination for everyone who wants to improve the quality of her/his life, looking forward to a better future. An Important role in the selection of the EU as the final destination of immigrants is also the proximity to Asia and Africa [Figure 1 about here].

However the management of this phenomenon by the Hellenic LEAs is difficult, because Hellas is the meeting point of two continents and also is located at the crossroads of maritime and land routes between east and west. Specifically the Hellenic geopolitical reality comprises the following characteristics:

a. - The Extensive Hellenic coastline (almost $18.400 \mathrm{~km}$ ), the second longest in Europe (after that of Norway), which is equal more or less to the two thirds of the perimeter of Africa. 
b. - The Existence of numerous rock-islands (more than 9000), which create a space accessible from many directions.

c. - The Proximity of the Turkish coastline (from which enter the main illegal migration flows), to the East Aegean Hellenic Islands that give sthe advantage to the smuggling links to organize "transfers".

d. - The Heavy maritime traffic, of all kind of vessels in the sea.

e. - The extensive land border with Albania (246 km), FYROM (245 km), Bulgaria (476 km) and Turkey (203 $\mathrm{km})$, total :1170 km [Figure 2 about here].

\section{The Illegal Immigration in Hellas and Its Characteristics}

Hellas until 1990 had a population that was $98.5 \%$ ethnic Hellenic with a small Muslim minority. Since 1990, at least a million immigrants arrived in Hellas and so now the immigrants comprise at least $10 \%$ of the Hellenic population.

This was a new experience for Hellas. The immigrant flows originally came from the Balkans or the Former Soviet Union, basically many Albanians, Romanians, Ukrainians, Russians. But the last few years the immigration flows have changed. They now come from the greater Middle East (Iraq, Afghanistan) or the subcontinent (Pakistan, India). These inflows are creating a new situation for Hellas [Figure 3 about here].

Specifically, according to EUROSTAT (Note 1) elements as far as it concerns Hellas, indicate that Hellas hosts the second largest proportion of foreigners from outside Europe after Spain.

Particularly in Hellas in 2010 there were officially 954.800 foreigners (8.4\% of total population), of whom $163.100(1.4 \%)$ were citizens of EU/MS and 791.700 (7\%) came from other countries.

A greater deterioration of the national and European nature of its population only Spain has. Immigrants who came from countries outside of EU are $7.3 \%$ of the population. Very high percentages are shown also in Latvia (17\%) and in Estonia (15.1\%), but this is due to native Russian-speaking populations that they live there.

Spain has also attracted a much larger proportion of EU citizens (5.1\%), while after Luxembourg, the administrative center of the EU, Cyprus hosts a large percentage of EU citizens amounting to $10.4 \%$ of the population.

Overall in the EU of $27 \mathrm{MS}$, citizens who are residing in a country other than their origins reach 32.4 million people, $6.5 \%$ of the population. The internal migration reaches $2.5 \%$ and 12.3 million people, while immigrants from other countries amounted to $4 \%$ of the total population or 20.1 million people.

The illegal immigration is not a narrow Hellenic problem, because the immigrants that come from the Middle East to Hellas aspire to go to Germany or to other Western European countries that are richer than Hellas, as there are also strong communities of their compatriots.

Hellas has emphasized that this is a European problem and it is getting more and more pressing now. EU has agreed on this approach and has become a European affair for FRONTEX. Members of the EU today have naval or air units in the Hellenic islands, opposite Asia Minor. And whereas in 2008 this was a FRONTEX operation that lasted for a few months in the year, in 2009 it became a permanent operation for twelve months. So permanently, there are naval and/or air units stationed in the Hellenic islands from the EU member states, patrolling, policing Hellas sea borders to stem the inflow of immigrants (Note 2).

Unfortunately from the Hellenic perspective and European perspective the cooperation of Turkey in controlling and stemming this inflows are less than what Hellas and EU expected, given the bilateral agreement that Hellas signed a few years ago (Note 3). Additionally, the lack of a continuous, consistent and rational immigration policy by the Hellenic State (Note 4), in combination with the lack of adequate infrastructure for the hosting of illegal immigrants entering in order then to be implemented the provided legislation procedures (Note 5) and the unwillingness on the part of Turkey to cooperate, has led to an explosive social situation in Hellas. A situation which should be considered in relation to the economic crisis which has dominated the country for the last years.

\subsection{Dublin II regulation (Note 6)}

The Basic legislation governing in general immigration policy topics is the Dublin II Regulation. The provision of this regulation has created many problems to Hellas. The purpose of this regulation is to establish criteria and mechanisms for determining the Member State which is responsible for examining applications for asylum submitted by a citizen of a third country. The Member State examines each application for asylum submitted by a citizen of a third country at the border or within the territory. The application is examined by a single MS which is designated as responsible under the criteria set out in the rules in Chapter III. 
In particular in Article 10 of this regulation it is stated that: 1. Where it is established, on the basis of proof or circumstantial evidence as described in the two lists mentioned in Regulation (EC) No 2725/2000, that an asylum seeker has irregularly crossed the border into a Member State by land, sea or air having come from a third country, the Member State thus entered shall be responsible for examining the application for asylum. This responsibility shall cease 12 months after the date on which the irregular border crossing took place.

Notwithstanding the foregoing, each MS may examine an asylum application which was submitted by a citizen of a third country, even if it is not responsible for the examination, under the criteria laid down in this Regulation. In this case, that MS is the responsible State within the meaning of this Regulation and shall assume the obligations associated with that responsibility.

Each MS retains the right to promote, under national law, the asylum seeker to a third country in accordance with the provisions of the Geneva Convention. The process of determining the responsible MS according to the provisions of the Regulation starts when for the first time is submitted an asylum application in a MS.

The continued imposition of the criterion of first illegal entry, as provided in the Dublin II Regulation, beyond any doubt, is contrary to the principle of equitable sharing responsibility, also it is in direct opposition to the support policy to the MS at the external borders and counter to the logic of this regulation which combines the identification of the responsible MS in some form of "responsibility" for entering the Schengen area.

For most of the MS it is not even possible for the first illegal entry out of border checkpoints (e.g. Luxembourg), while for others (e.g. Ireland, Denmark, Norway), the first illegal entry by land or sea is an entirely theoretical possibility. Therefore, a criterion which is not related by definition to all MS but only to certain of them is directly contrary to the principle of equitable sharing of responsibility. This criterion burdens precisely these MS which EU seeks to strengthen through practical cooperation and financing, because it is believed that they offer services to the whole EU. It is an oxymoron status, for which the EU has been challenged by international governmental and non-governmental organizations.

Hellas believes that the procedure under the Dublin II Regulation fails completely to address the fact that the vast majority, if not all, of the people who are crossing illegally from the Hellenic border have as final destination (e.g. search for relatives) other MS. Under the current institutional framework, these people are caged in Hellas, which has been converted into the warehouse of Europe (Note 7).

\subsection{Facilitators modus operandi}

Of the incidents of illegal immigrants transportation which have been treated by the Hellenic LEAs it has been revealed that the facilitators follow the below following methods:

(1) The immigrants embark from the Turkish coasts on a vessel with the smuggler travelling among them. After reaching the Hellenic coasts the immigrants are disembarked and the smuggler returns back to the starting point.

(2) The vessel carrying the illegal immigrants, operated by the Turkish smuggler departs from the Turkish coast accompanied by a second vessel on which the smuggler's collaborators are carried. During this trip the smuggler informs one or more of the immigrants about how to operate the vessel and when they reach a point, usually close to the borderline, he abandons the vessel embarking on the second vessel operated by his collaborators and then they return to Turkey. Then, the vessel with the immigrants continues the trip headed to the point of disembarkation operated by the immigrants themselves.

(3) The Turkish smugglers are not aboard the transportation vessel since they train a migrate how to operate it and eventually he makes the transport himself from the Turkish coasts to the Hellenic islands.

(4) From various points of Asia Minor, immigrants of Afghan origin - in groups of three people - embarked on small inflated rubber boats, using oars, and disembark on the adjacent Hellenic islands, mainly at Kos, Chios and Samos. Such incidents are recorded almost daily from the end of the year 2000 onwards. In this case, the Turkish smugglers provide the immigrants with rafts and their Hellenic collaborators forward them from the islands to the Hellenic mainland using regular service passenger ships.

(5) Illegal transport of immigrants with big yachts or fishing boats or cargo ships is usually organized at the immigrant's country of origin. Different points of disembarkation are selected each time by members of the criminal syndicates which are always isolated and difficult to access. The crews of these ships usually stay aboard all the time, and after the disembarkation has been completed they return to the countries from which they had departed and stay there until they find new «cargo». This method is mostly used by facilitators with Arab nationalities whose vessels are departing from East Mediterranean countries (Lebanon, Syria, Egypt etc). 
Incidents have also been recorded when the crews of the ships carrying illegal immigrants - during the night and close to the Hellenic territorial waters - flee the vessel and embark on other vessels accompanying the ship thus abandoning the immigrants who are usually located by other ships sailing nearby or by the Hellenic Coast Guard patrol boats. In cases where ships carrying illegal immigrants pass through the Hellenic islands, headed to other European countries, the smugglers come from the same starting points, using the same methods and following routes passing south of Crete in the high seas or through the Aegean Sea usually under bad weather conditions and far from coasts.

(6) As regards the land border passing methods which are followed by the illegal immigrants and smugglers, are the entering in Hellas from unattended mountain passes or from unsecured parts of the Hellenic border. Also illegal immigrants are trying to enter into Hellas carefully hidden in trucks or buses as travelers. In particular at the land border between Hellas - Turkey where the Evros River is the main natural border, the illegal entry can be effected by inflatable boats or rafts or boats operated by facilitators or illegal immigrants in order to reach unattended points of The Hellenic -Turkish border avoiding as possible the military and police patrols [Figures 4 and 5 about here].

\section{Europol}

The European Police Office (Europol) was agreed in the Treaty of the European Union of February 7 1992, and the relative arrangements contained in the Convention of establishing the European Police Office ("Europol Convention") [EU 316/27-11 -1995] Article K.3 of the Treaty for the European Union.

By the Council Decision issued on 6 April 2009 [EU L 121/15-05-2009] which came into force from 01.01.2010, the provisions of the convention which were mentioned above were replaced and Europol under this Decision shall be deemed as the successor of Europol as established by the Europol Convention.

The basic arguments of EU institutions, which led to the preparation and adoption of the Council Decision of 06 April 2009 were:

1. - The creation of Europol as an EU institution financed by the general budget of the EU would strengthen the role of Parliament in relation to the control of Europol.

2. - The inclusion of Europol to the general rules and procedures applicable to similar agents of EU, would ensure administrative simplification, so that Europol would be able to devote more of its resources in fulfilling the main tasks.

3.- Further simplification and improvement of Europol's functioning could be achieved by implementing measures that will be focused on expanding its capacity, in order to assist and support the competent LEAs of MS, without conceded executive powers to its staff and

4. - One of these improvements was to ensure the possibility for Europol to assist the competent LEAs of MS to combat specific forms of crime, without the restriction in force under which there should be real evidence of the involvement of organized criminal gangs.

The headquarters of EUROPOL, which has legal personality, is located in The Hague, Netherlands. It has a staff of approximately 700 officers who come from 27 MS of the EU. Europol's staff is recruited from different LEAs, including police, customs, border police, coast guard and security services.

Europol's competences are organized criminal group (OCG) (Note 8), terrorism and other serious crime such as drug trafficking, illegal immigration, human trafficking, money-laundering, crimes related to motor vehicles, swindling etc. (for more details see Article 4 of Council Decision in conjunction with the Annex) affecting two or more MS, in a way that requires a joint approach by the MS, given the scope, significance and consequences of criminal acts.

At EUROPOL premises are also posted liaison officers from the $27 \mathrm{MS}$ as well as the liaison officers from other countries or organizations with which Europol has signed cooperation agreements (agreements divided into strategic and operational) (Note 9). Their number is about 120 and they are entrusted by the national unit to represent its interests within Europol in accordance with national law of the MS which has separated them and the provisions which are applicable to the administration of Europol.

It should be noted that in order to be simplified the exchange of information and intelligence between the LEAs of EU, the Decision - Frame 2006/960/JHA issued on 18 December 2006 has been adopted [EU L 386/29.12.2006].

With this decision the MS ensure that the procedures allow them to respond within 8 hours, in urgent requests for information and data relating to the offenses of paragraph 2 of Article 2 of Decision - 2002/584 Framework / JHA [EU L 190, 18-07-2002], where the requested information and data are held in a database directly accessible to LEAs. 
In order for EUROPOLs work to be supported, at the EUROPOL National Units and at the offices of the liaisons officers exists a secure telecommunications infrastructure along with systems for information elaboration (Note 10) - Chapter II of Council Decision - and in Chapter III the rules for information processing are set out . A high protection in the database under an institutional framework that clearly defines the procedures for keeping, sharing and deleting data, ensure that the information managed by EUROPOL and especially all the procedures followed are in line with the provisions of personal data protection.

The main activity of EUROPOL is the supporting of the MS in the collection, analysis and distribution of information relating to crime and to coordinate operations. For this purpose, the EUROPOL has over 100 information analysts.

The MS which are facing a specific criminal phenomenon that affects two or more MS/EU may request from EUROPOL to open an analytical work file (Analysis Work File-AWF) to support research in this field. The EUROPOL provides assistance for current operations through 23 Analytical Work Files and in themes within the circle of competences. An AWF is the primary means by which Europol offers operational analytical support to investigations within the Member States As far as the illegal immigration is concerned the AWF is called Checkpoint. The purpose of AWF Checkpoint is to assist Member States in preventing and combating the forms of criminality associated with the facilitation of illegal migrants within and into the European Union by organized crime groups.

Operational and personal data can be exchanged between the members of an AWF, with analytical support (Note 11) provided by Europol. Data can also be contributed from EU Member States that are not members of the AWF. Any third state or international organization can contribute data to be used in an AWF and may, under special conditions, be invited to become associated members of an AWF. Contributions to the AWF have to be forwarded via the Europol National Units. All data regarding serious crime in relation to facilitated illegal immigration can be accepted by AWF Checkpoint. The Organized Crime Groups facilitating illegal immigration are very active and flexible and in line with the legal framework a large number of contributions to the AWF Checkpoint are is received. In order to be able to provide the best support to live, ongoing pan-European operations/investigations the AWF Checkpoint is focused on nationalities or key areas which are particularly affecting the EU MS. The focus of Europol's support will be prioritized in consultation with the affected EU MS (Note 12).

Important areas of Europol's staff activity comprise the participation with a support capacity character in joint investigation teams (JIT) (Note 13)with a scope to providing assistance for all activities and exchanging information with all members of the JIT, without participating in coercive measures.

From the above it is clear that EUROPOL is a supported European service offering through specific processes expertise to LEAs without actively participating in operational processes rather than the analyzing of operational information.

\section{Frontex}

The Council of EU estimated that the objective of EU policy for the external borders of EU is the integrated management (Note 14), in order to ensure uniform and high level of control and surveillance, which are a necessary consequences of the free movement of persons in EU and fundamental components of freedom, security and justice and for this purpose it is predicting the establishment of common rules on standards and control procedures at external borders in conjunction with the fact that the responsibility for control and surveillance of external borders lies with the MS. Thus it established in 2004 the European Agency under the name FRONTEX, aiming at managing operational cooperation at external borders in order for an integrated management of external borders of MS/EU to be achieved.

The Agency is located in Warsaw (Poland) (Note 15), and the main duties which are operational as opposed to the supported nature of the tasks of Europol, consist (Note 16):

- Coordination of operational cooperation between MS as regards the management of the external borders.

- Carrying out risk assessments.

- Providing assistance to MS on the training of national border guards, including the establishment of common training standards.

- Monitoring developments in searches related to control and surveillance of external borders.

- Assisting contribution to MS in circumstances requiring increased technical and operational assistance at external borders. 
- Providing the necessary support to MS in organizing joint read miss operations.

-Sending at MS Rapid Border Intervention Team (RABIT) in accordance with Regulation No 863/2007.

It must be noted that from the start until now the agency has undertaken a number of important actions and initiatives such as:

-Conducting joint European operations at sea borders.

-Establishing a European network of patrols.

- Establishing a central registry of available equipment.

- Development of Rapid Border Intervention Team.

- Training of border guards - keeping common training standards.

EUROPOL and FRONTEX have signed agreement in order to enhance the cooperation between Europol and Frontex, in particular through the exchange of strategic and technical information. This Agreement does not authorise the transmission of data related to an identified individual or identifiable individuals (Note 17).

\subsection{RABIT operation}

On the basis of operational data gathered during the implementation of Operation RABIT, Frontex confirms further decreases in the number of irregular migrants detected at the Hellenic -Turkish land border.

Specifically throughout the year 2010, October saw the maximum number of migrants apprehended (7607), with an average of 245 detections per day. Since the beginning of Operation RABIT 2010, a decreasing trend in the number of detections was observed compared to October: in November (4631) and December (3423) the average daily detection rate fell to $154(-37 \%)$ and $110(-57 \%)$ respectively.

In the first week of 2011 (data until January 8, 2011), a total of 686 persons were detected crossing the green border illegally. The average number of migrants apprehended per day decreased further to approximately 98 .

The approximately 200 guest officers and interpreters sent to Hellas by Frontex are under the command and control of the Hellenic authorities and are mainly involved in patrolling the border and collecting information about the people-smuggling networks facilitating the arrival of the migrants.

Since June 2, 2010, over 38,000 undocumented persons have been detected crossing the Hellenic -Turkish land border. The largest group (44\%) comes from Afghanistan while the other most numerous nationalities are Algerian (16\%), Pakistani (8, 5\%), Somali (6\%) and Iraqi nationals (4\%).

Last year 45 people lost their lives trying to cross the Evros River, or at sea in the area of Alexandroupolis: 26 within the operational area of Orestiada, four at the banks of the Evros and 15 at sea in the vicinity of Alexandroupolis. In the first week of January alone four bodies were found in the area - all young males who had died of hypothermia.

"These people were put on rubber boats or told to swim or cross the freezing cold river by the facilitators," said Frontex Deputy Executive Director Gil Arias Fernandez. "In fact, an important target of our operation is the criminal facilitation networks that are behind these arrivals."

Since the start of Operation RABIT 2010, some 22 facilitators have been arrested, from Turkey (9), Afghanistan (4) Bulgaria (4) Palestine (3), Syria (1) and Georgia (1).

Frontex still continue to provide operational support to Hellas after the end of the RABIT deployment (March 2011), through Operation Poseidon Land (Note 18). RABIT completed its operation on 03.02.2011.

At the time of operation RABIT 2010 recorded a significant reduction of approximately $76 \%$ of the average daily number of illegal immigrants who crossed the Hellenic - Turkish land border from October 2010 until February 2011, particularly along the 12, $5 \mathrm{~km}$ area near Orestiada/Hellas. From November 2, 2010 till 1 March 2011, a total of 11.809 immigrants were erected, while they were trying to cross the border illegally. Moreover, during the said period, 34 traffickers coming from Turkey, Afghanistan, Bulgaria, Palestine and Georgia were arrested. From the end of January 2011, until the completion of the operation RABIT 2010, the number and percentage of detections remains at the same level - the average number of immigrants who were contacted per day was 58. The percentage of detections between the Police Divisions of Alexandroupolis and Orestiada was approximately $65 \%$ and $35 \%$ respectively. Before undertaking RABIT 2010, the maximum number of immigrant arrests in The Hellenic - Turkish land border was recorded in October, with an average of 245 scans per day (Note 19). 


\subsection{Poseidon joint operations 2011(Note 20)}

Poseidon joint operations are the operations carried out by FRONTEX at the external borders (land, sea and air) of MS/EU. On 22/10/2010 in Warsaw under the auspices of FRONTEX, the «Annual Bilateral Discussions» (Annual Bilateral Talks) for the definition of joint operations took place. In this context, and for 2011, Hellas agreed to host the Joint Operation under the name POSEIDON 2011. The purpose of POSEIDON 2011 consists in continuing the growing of FRONTEX forces in the Hellenic-Turkish border in order to strength efforts to tackle illegal immigration. For the Hellenic -Turkish land border POSEIDON 2011, began on 3/3/2011 and will end on 01/05/2012, while for the sea Hellenic -Turkish border it began on 1/4/2011 and will end on 31/12/2011.

The Joint Operation Poseidon was conducted in previous years partially in 3 to 4 phase monthly period. But given the increasing migratory pressure, recorded in the Evros region from 2010 it was decided that the operation will be conducted without time gaps with a view to the continuous surveillance of The Hellenic-Turkish land border with increased forces.

For the coordination of the operation and in order to achieve its objectives the establishment of the International Coordinating Center (ICC) based in the Police Department of Kipi was predicted as well as the establishment of Local Coordinating Centers (LCC's) at the Police Divisions of Alexandroupolis and Orestiada.

The direct control and supervision of the implementation progress of the operation (preparation, implementation and evaluation), and the responsibility of coordinating cooperation in taking the necessary measures in all areas of operations (Police Divisions of Orestiada and Alexandroupolis) in order to ensure the objectives of the operational plan are assigned to the Executive Director of Eastern Macedonia and Thrace (Hellenic Police), who is appointed as head of the International Coordinating Center.

Considering the situation in Tunisia and Egypt estimation for participation in the operation of the Hellenic Coast Guards Authorities and Police Authorities of Crete and southern Peloponnese, if it is necessary has been made.

In joint command operation POSEIDON LAND 2011(Note 21) officials with various duties are involved such as: coordinators, supervisors land borders, police dog escorts, drivers of vehicles, persons responsible for detection of forged documents and persons responsible for passport control. Regarding the technical support of POSEIDON LAND 2011 it includes: patrol, transport vehicles and police dogs and vehicles with integrated thermal imaging and mobile Coordination Centers.

The joint European operations in cooperation with the Hellenic authorities and Frontex were held in the last year.

The Hellenic Police, the Hellenic Coast Guard and Frontex forces almost from all countries of EU are attempting to land borders in Evros and in the sea border at the areas of Samos, Lesvos, Chios, Dodecanese and Crete.

For land borders there are available in Hellas:

- 453 officers from most MS/EU, 2 aircraft, 1 helicopter, 58 vans with integrated thermal imaging detectors, 3 heartbeats, 1 motion detector system (radar), 19 police dogs, 1 bus, 32 patrol vehicles, 13 computers.

For sea borders there are available in Hellas:

- 56 officers, 8 fast patrol boats, 1 vessel for open sea, 4 helicopters, 2 planes, 1 interpreter.

At the land borders with Turkey in order to tackle the problem of illegal immigration (Figure 5 about here) it was decided by the Hellenic authorities to construct an artificial barrier (fence) with a total length of approximately $10.3 \mathrm{~km}$ at the northeastern part of Hellas along the land border with Turkey The artificial barrier will beconsisting of double fencing wire on strong poles that consists of galvanized steel and standard typical cross sections. Between the two fences steel wire will be installed (Note 22) (Figure 6 about here).

\section{Hellas Actions and Policy}

Hellas supports the formation of a common EU migration policy based on the following principles:

1.-Protection of external borders of $\mathrm{EU}$ in order to reduce the illegal immigration.

2. -Fast and fair consideration of requests for political asylum.

3. -Support of European initiatives for peace, democracy, development and job creation in countries of origin in order to reduce the migration pressure on Europe and Hellas. 
4. -Support of social inclusion and integration of legal immigrants living in the EU. Supports the establishment of a Common European Asylum System, based on the principles of solidarity, shared responsibility and growing cooperation. During the creation of a new European immigration policy, it proposes a revision of the regulation "Dublin II" for asylum because it shifts the burden of examining such requests only on in countries that are located at the external borders of EU. The European Commission, FRONTEX and the European Asylum Support Office should play an important role in supporting and assisting Hellenic national efforts to combat illegal immigration and asylum management.

At the Headquarters of the Hellenic Coast Guard in Piraeus the Operation Office of FRONTEX is hosted, which coordinates activities in sea and land borders in Southern Europe. In June 2011, the study for the design and development of the National Border Surveillance System and the preparation of technical specifications for the technical equipment of the National Coordinating Center was completed, according to the design requirements of the European Union for the developing of the European Surveillance Border System (EUROSUR), and the National Coordinating Center was also established

The process of project implementation will begin in the coming months (public consultation - call) in order for the objective set by the EU for Hellas to be achieved, namely the operation of this Center (National Coordination Center) in 2013.

In the mean time the Hellenic authorities in cooperation with the European Commission formed the program of integrated border management to tackle illegal migration.

The entire program will be funded with 275 million Euros, from:

a. National Resources, with around 55 million Euros.

b. The External Borders Fund with about 200 million Euros.

c. Grants from the European Economic Area (Norway, Switzerland, Iceland, Liechtenstein) with 20 million Euros The integrated management program of the borders in order to combat illegal immigration includes:

a. Installation of automated border surveillance using thermal cameras on masts at fixed points and use special detection software. The system will be installed in the terrestrial part of The Hellenic-Turkish border in the region of Orestiada. The project is in cooperation with the National Technical University.

b. Supply of 2 helicopters equipped with thermal imaging cameras.

c. Supply of 5 motor operational centers (VAN), equipped with radar and thermal imaging camera.

d. Supply of 4 auto vehicles X-ray units, for imaging (scanning) the interior of vehicles and identify

Illegal immigrants in specially designed vaults.

e. Supply of 40 portable thermal imaging cameras.

f. Supply of $2104 \times 4$ jeep-type vehicles.

g. Supply of criminal intelligence analysis software i2, along with the necessary electronic equipment

h. Procurement of 44 specially trained patrol dogs with 44 special vehicles transporting them.

i. Installing and operating Schengen Information System, second generation (SIS II).

Especially for the Hellenic Coast Guard it proposes:

a. Supply of 6 coastal patrol vessels (OPV), length $20 \mathrm{~m}$, all-weather and speed from 30 to 40 knots / hour.

b. Provision of a vessel for open sea (POS), length $50 \mathrm{~m}$, and operational speed of 25 knots.

c. Supply of 2 fast patrol boats (inflatable).

d. Equipment for the Coordinating Center of the Hellenic Coast Guard.

e. Installation of RADAR for the surveillance of sea borders in the North Aegean.

f. Planning for commission of 25 portable field glass thermal imaging.

g. Supply of 15 binoculars for night observation.

h. Procurement of 30 vehicles type jeep $4 \times 4$.

i. By statutory provision any car, boat or private aircraft used in an illicit trafficking of immigrants will be seized immediately. These resources will be available to the Hellenic Police and Hellenic Coast Guards authorities. 
k. Construction and equipment of buildings for housing the Police Department of Border Police in the areas of Konitsa, Delvinaki, Feres and Didymoticho.

1. The Program of renovation and equipment of approximately 15 Police Services in Epirus/Hellas and North Aegean Islands is running.

m. Participation with 4 million Euros in financing visa system (Visa Information System), project with budget of 19 million Euros, which is implemented by the Ministry of Foreign Affairs(Note 23).

\section{Conclusions}

The phenomenon of illegal immigration which is a problem for most of MS/EU, is noticeable in Hellas, given its geographic location, specific nature and extent of its borders and its proximity to Turkey. These make Hellas a hub for trafficking illegal immigrants. Therefore there is imperative need for effective border surveillance.

The surveillance of land and sea borders is a matter of general security. The close cooperation of the Hellenic Police, Hellenic Coast Guard with other organizations in Hellas and especially with units which bear surface radars, with naval units patrolling at sea, with observations of the Armed Forces is necessary. The use of other means for surveillance of borders, such as satellites, unmanned aircraft, airships equipped with sensors, etc may also be necessary. Cooperation with agencies using similar technology and businesses that can help with their expertise is essential.

Hellas should pursue through appropriate foreign policy to address the general problem of illegal immigration in international organizations (UN, EU, OSCE), so that everyone should understand the situation and circumstances faced by Hellas on behalf of the whole EU. It is understandably important in order for this phenomenon to be tackled for Turkey to be pressed in particular through the EU to implement the agreement signed between Hellas and Turkey for the readmission of illegal immigrants entering the EU through Hellas.

At a European level, Hellas should continue, as it does, to participate actively in European offices and agencies (Frontex, Europol etc.) and in other initiatives in order to utilize their best capabilities and expertise provided by these agencies for overcoming this problem. At the same time it must seek to make the MS/EU society co-managers of the problem facing its border with the trafficking of immigrants, which is achieved by the presence of border guards from other MS in Hellas by FRONTEX. These officers will become familiar with the situation especially in the Hellenic -Turkish border, carrying the experiences to their country. Additionally, their presence ensures the Hellenic borders as borders of the EU, with understandable consequences for the relations between Hellas and Turkey.

The Common European Asylum System cannot be built properly if it is not corrected, with the Dublin II Regulation on the basis of the first illegal entry. The EU if it really wants to promote the institutional patented principle of equitable sharing responsibility, should and must soon take concrete steps in this direction. The emergency mechanism is only a little solidarity, but it has little to contribute to MS which are accepting high pressure in the external borders.

The Dublin II Regulation in its current form disproportionately obstructs the MS which as mentioned before accept the most pressure on their borders of illegal immigrants. The regulation should be changed in order for the burden to be shared equally in the EU and not the MS which receives firstly the illegal immigrants to manage the whole issue. Especially the MS of The Mediterranean are feeling the highest pressure because of this phenomenon with strong effects on the social, economic and political structure of their societies (Spain, Hellas, Italy).

As regards Hellas, the majority of illegal immigrants do not intend to remain in it, but they use Hellas as a platform in order to be transferred to the MS of the EU in Western Europe.

The axes of the revision of this regulation should be the elaboration of a coherent and comprehensive European Migration and Asylum Policy, which moves in the basis of solidarity, equal and joint sharing of responsibilities and burdens and takes care to reinforce the deterrent capacity of Member States at the External Borders in order to deal uncontrollable inputs from other points of entry (not officially).

Effective border control is a challenge and requires a multifaceted effort at European level and also at national level and the two policies should be thus complementary.

The MS obviously cannot provide by themselves solutions to this global phenomenon. It is required that international initiatives which in any case should be taking into account the legal instruments for protection of human rights are considered.

The design of effective immigration policies long term in conjunction with the secure storage - border surveillance might help to reduce the number of illegal immigrants in the EU but the phenomenon, as is well known due to 
socio-economic reasons in the EU should primarily address the places in which it was first created. Financial support, capacity building, provision of expertise/knowhow, economic convections etc., or else the economically active foreign policy of the EU is potential to yield more results in contrast to the intensity of measures for surveillance and guarding borders measures which in the final analysis are police suppression ones .

\section{References}

Markezinis, V. (2011). Hellas of Crisis, A.Libanis, Athens.

Mposi, M. (1999). Security issues in the new world order. Papazisi, Athens.

Nomikos, J. (2010). Illegal immigration and organized crime in Greece. Research Paper No. 144, Research Institute for European and American Studies (RIEAS).

Papakonstantis, G. (2004). Modern Security Threats, $2 \eta$ d edition. Rethymnon.

Romanos, K. (2009). Ongoing ethnocide - Hellas on the eye of the storm of the New Order. Pelasgos, Athens.

\section{Notes}

Note 1. See newspaper «ETHNOS», issued on 01/04/2011 article titled, «Nearly 800,000 immigrants from outside the EU are in Hellas».

Note 2. As regards the protection of sea borders, in the Headquarters of the Hellenic Coast Guard, there has been established a Division which bears the same title and is responsible for tackling illegal immigration [Article 20, P.D. 67/2011 (A'149)].

Note 3. See L. 2926/2001 (A` 139), «Ratification of the Agreement between the Hellenic Republic and the Republic of Turkey on cooperation with the Ministry of Public Order of the Hellenic Republic and the Ministry of Interior of the Republic of Turkey to fight crime especially terrorism, organized crime, drug trafficking and illegal immigration» and L. 3030/2002 (A' 163), «Ratification of the Protocol on the application of Article 8 of the Agreement between the Government of the Hellenic Republic and the Government of the Republic of Turkey for combating crime, especially terrorism, organized crime, drug trafficking and illegal immigration».

Note 4. As regards the entry, residence and social integration of third country nationals on Hellenic territory relative are the provisions of L. 3386/05 (A' 212), as amended and in force by L. 3772/2009 (A' 112).

Furthermore EU legislation and documents for illegal immigration are:

- Directive 2002/90/EC (OJ L 238, 5-12-2002, p.17) defining the facilitation of unauthorized entry, transit and residence.

- Framework Decision 2002/946/JHA (OJ L 238, 5-12-2002, p.1), on the strengthening of the penal framework to prevent the facilitation of unauthorized entry, transit and residence.

- Council Directive 2004/81/EC (OJ L 261, 6-8-2004, p.3) on the residence permit issued to third country nationals who are victims of trafficking in human beings or who have been the subject of an action to facilitate illegal immigration, who cooperate with the competent authorities.

- Council Directive 2004/81/EC (OJ $1261,6-8-2004$, p.3), on the residence permit issued to third-country nationals who are victims of trafficking in human beings or who have been the subject of an action to facilitate illegal immigration, who cooperate with the competent authorities

- Council Conclusions on 29 measures for reinforcing the protection of the external borders and combating illegal immigration (6975/10 ASIM 33 FRONT 24 COMIX 158)

Note 5. In English there is a distinction between the terms immigration policy - immigration policy, and immigrant policy - political solution to the problems of immigrants. Immigration policy is always a government policy driven by the national interest. It determines how many immigrants need the national economy, from what countries, what specialization, for how long etc. On the other hand, the policy for immigrants is primarily a social policy aiming to ensure equality and other humanitarian principles governing the culture of the country for legal immigrants. This distinction is deliberately by passed in Hellas. In Hellas the notion of policy for immigrants is only propagandized and carefully avoided formulating a rational immigration policy. See Konstantinos P. Romanos, «Ongoing ethnocide - Hellas on the eye of the storm, of New Order», Pelasgos, Athens, 2009, p. 104. For the same subject see also V. Markezinis, Hellas of Crisis, A. Livanis, 2011, p.p. 288 and next.

Note 6. Regulation (EC) No 343/2003 issued on 18 February 2003 related on criteria and mechanisms for determining the Member State responsible for examining applications for asylum which had been submitted in a 
Member State by a citizen of a third country [L 50/25.2. 2003] in conjunction with the provisions of Regulation (EC) No 2725/2000 and in particular Chapter III

Note 7. See press Release Ministry of Hellenic Ministry of Citizen Protection on 18/07/2011, available from http://www.minocp.gov.gr/index.php?option=ozo_content\&perform=view\&id=3743\&Itemid=504\&lang

Note 8. See L. 3975/2010 (A' 158)] and analytical document No 6204/2/97 ENFOPOL 35 REV 2 of EU Council. In particular and concerning the characterization of an illegal action as a form of organized crime according to the above mentioned document and after a lot of discussions it was agreed by MS that in order to integrate a crime to organized crime there should be kept at least six of the following characteristics, among which coexist necessarily those mentioned in items $1,3,5 \& 11$ :

a. Co-operation between more than two persons.

b. Sharing tasks.

c. Long or indefinite duration.

d. Some form of discipline (the organization's activities to be implemented in accordance with a defined set of rules).

e. Suspicion of committing serious criminal offenses.

g. International action (activities of the organization should cover more than one country).

h. Use of force or other forms of intimidation (the use of violence or intimidation are part of the usual methods of action of the organization).

i. Use of commercial and operational structures (to control the profits).

j. Involvement in money-laundering (money laundering).

k. Influencing the fields of politics, media, public administration, judicial authorities or the economy

1. Min-profit making and / or power as a key objective

Also see «The future of organized crime», «Conclusions from the European Police Chiefs Convention, European Police Chiefs Convention», European Police Office, 2011, p.p.10-13, «Illegal immigration and organized crime in Greece», John Nomikos, Research Paper No. 144, August 2010, Research Institute for European and American Studies (RIEAS), p.10 and next, Georgios Papakonstantis. «Modern Security Threats, 2ๆd edition», Rethymnon, p.p. 30-33 and generally Mposi M., «Security issues in the new world order», Papazisi, Athens, 1999.

Note 9. Analytically there have been signed the following agreements:

Operational: Canada, Croatia, Eurojust, Iceland, Interpol, Norway, Switzerland, USA (ATF, DEA, FBI, ICE, USPIS, USSS) and Monaco.

Strategic: Albania, Bosnia Herzegovina, Civilian ESDP police missions, CEPOL, Colombia, European Commission, European Central Bank, European Anti-Fraud Office, Montenegro, European Monitoring Centre for Drugs and Drug Addiction, FYROM, FRONTEX, Moldova, Russia, Serbia, Turkey, Situation Centre of the European Council, United Nations Office on Drugs and Crime, World Customs Organization, Ukraine and is under progress agreement with Israel.

Note 10. The Europol Information System (EIS), allows the storing, searching, visualing and linking of information related to transitional crimes. It allows law enforcement agencies across Europe to cooperate on international investigations. The system automatically detects any possible hits between different investigations and facilitates the sharing of sensitive information in a secure and reliable way.

Secure Information Exchange Network Application (SIENA), is a new generation tool, which is used to manage the exchange of operational and strategic crime- related information between MS, Europol and third parties with which Europol has cooperation agreements. It operates in a way that complies with all the legal requirements of data protection and confidentiality.

Mobile Office, provides support for a wide range of activities such as ongoing investigations, major sport events, key international conferences and other occasions where a mobilization of police cooperation is needed to provide security. It can provide real- time, secure access to the different Europol computerized analysis system, data on people and phone numbers can be checked while the mobile office is deployed, the possibility to deliver on -the-spot analytical products such as reports, charts and other data, a satellite connection that increases the flexibility of the system. 
Note 11. Analytical support can be provided remotely from Europol premises or in the field. AWFs offer a variety of operational and strategic products which are shared among participants. Within an AWF, a specific target group or Joint Investigation Team can be set up to meet the needs of a group of MS and to tackle a common criminal phenomenon. Additionally Europol provides a rapid and flexible response to ongoing international investigations. The Europol operational centre (24/07/2011) is a central point where criminal information from multiple countries is cross - checked. See «The European Investigator, Targeting Criminals Across Borders», European Police Office, 2011, p.p. 7-9.

Note 12. See generally «The European Investigator, Targeting Criminals Across Borders», European Police Office, 2011. Also see «Europol Review, General Report on Europol Activities», European Police Office, 2011, p.p. 39-41.

Note 13. See EU L 185/ 16.7.2005, p. 35, EU L 162/20.6.2002, p. 1, EU C 197/12.7.2000, p. 3 and EU C 24/ 23.1.1998, p. 2.

Note 14. The EU policy for the management of external borders is reflected in institutional texts which were drawn up:

a. Treaty of Maastricht.

b. At the European Council in Tampere.

c. Treaty of Amsterdam.

d. At the European Council of Seville (2002).

e. At Thessaloniki European Council (2003).

f. In the Hague Programme (2004).

z. In The European Pact on Immigration and Asylum (2008).

Note 15. Council Decision 2005/358/EC issued on 26 April 2005 [L 114/13/4-5-2005].

Note 16. Regulation (EC) No 2007/2004 issued on 26 October 2004 establishing a European Agency for the Management of Operational Cooperation at the External Borders of the EU Member States and Regulation (EC) No 863/2007 issued on 11 July 2007 establishing a mechanism for the creation of Rapid Border Intervention Teams and amending Regulation (EC) 2007/2004 as regards this mechanism for regulating the duties and powers of guest officers.

Note 17. According to this agreement "illegal immigrant smuggling" means activities intended deliberately to facilitate, for financial gain, the entry into, residence or employment in the territory of the Member States of the European Union, contrary to the rules and conditions applicable in the Member States.

Note 18. See Frontex Press release, Warsaw issued on 12 January 2011

Note 19. Available from

$\mathrm{http}: / /$ www.astynomia.gr/index.php?option=ozo_content\&perform=view\&id=5164\&Itemid=529\&lang=\&lang. Also see Frontex News Releases «RABITS Operation 2010 Ends, Replaced by JO Poseidon 2011» issued on 03-03-2011.

Note 20. Conducted in The Hellenic -Turkish and Bulgarian land borders and in The Hellenic -Turkish sea border, involving personnel and equipment (air, water and land resources) allocated by the Member States of the European Union under the auspices, funding and coordination of FRONTEX. See FRONTEX News Releases «Update to Joint Operation Poseidon 2011» issued on 26-03-2011. Also see General Secretariat of the Council «European Council 24/25 March 2011 - Conclusions», Brussels, 20 April 2011, Euco 10/1/11, Rev 1, CO EUR 6, CONCL 3, p.10.

Note 21. See newspaper «Ethnos», issued on 10.01.2011, article «Additional help for Evros Calls Frontex» by C. Souliotis.

Note 22. See newspaper «Ethnos», issued on 16/10/2011, article titled «Fence $12.5 \mathrm{~km}$ on the Evros border» by Takis Terzis, also newspaper «Kathimerini», issued on 01/09/2011article titled «Viewpoint: The inalienable right to shield our borders» by Prokopis Pavlopoulos. More specifically the fence length will be about 10.3 miles from Chestnut Ebro/Hellas towards to New Vissa/Hellas. It will be consisting of double fencing wire and between the two fences steel wire will be installed. The outer fence will be up to a height of $2.5 \mathrm{~m}$ and $3 \mathrm{~m}$. In the interior there will be an intermediate corridor width $1.2 \mathrm{~m}$, in which officers will patrol. 
Note 23. See press Release of The Hellenic Ministry of Citizen Protection issued on 7-9-2011. [Online] Available: http://www.hcg.gr/node/1260

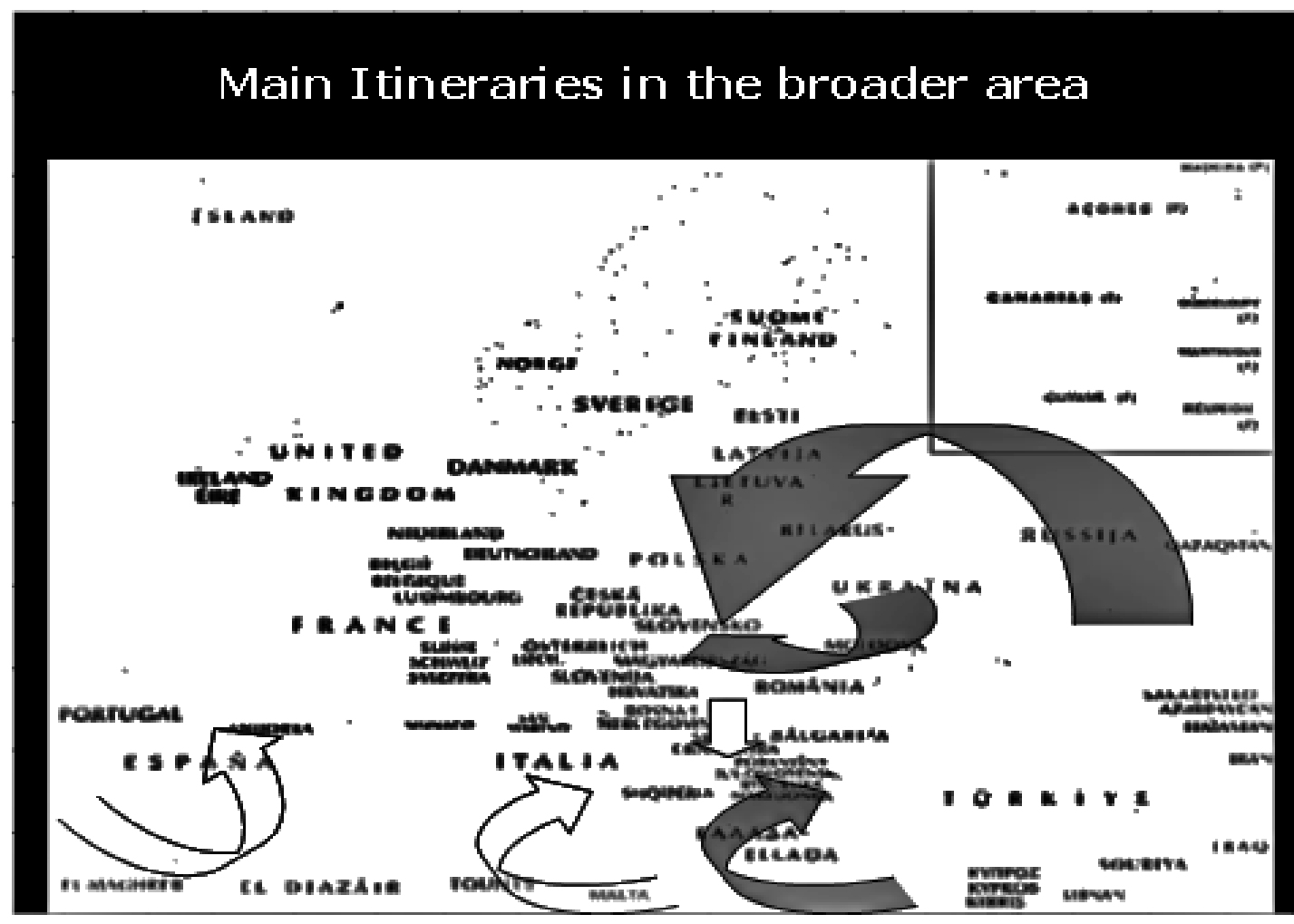

Figure 1. Main Itineraries in the border area

Source: Conference «ATHENA 09», Athens 10/2009. More specifically the «Athena 09» Crisis Management International Conference was the 12th annual "Athena" conference organized by the Hellenic National Defence General Staff (HNDGS) under the auspices - since 2008- of the Hellenic Ministry of National Defence. The «Athena 09» took take place in Athens from September 30th until October 3rd 2009 at Metropolitan Hotel. [Online] Available: http://www.geetha.mil.gr/index.asp?__id=2495 


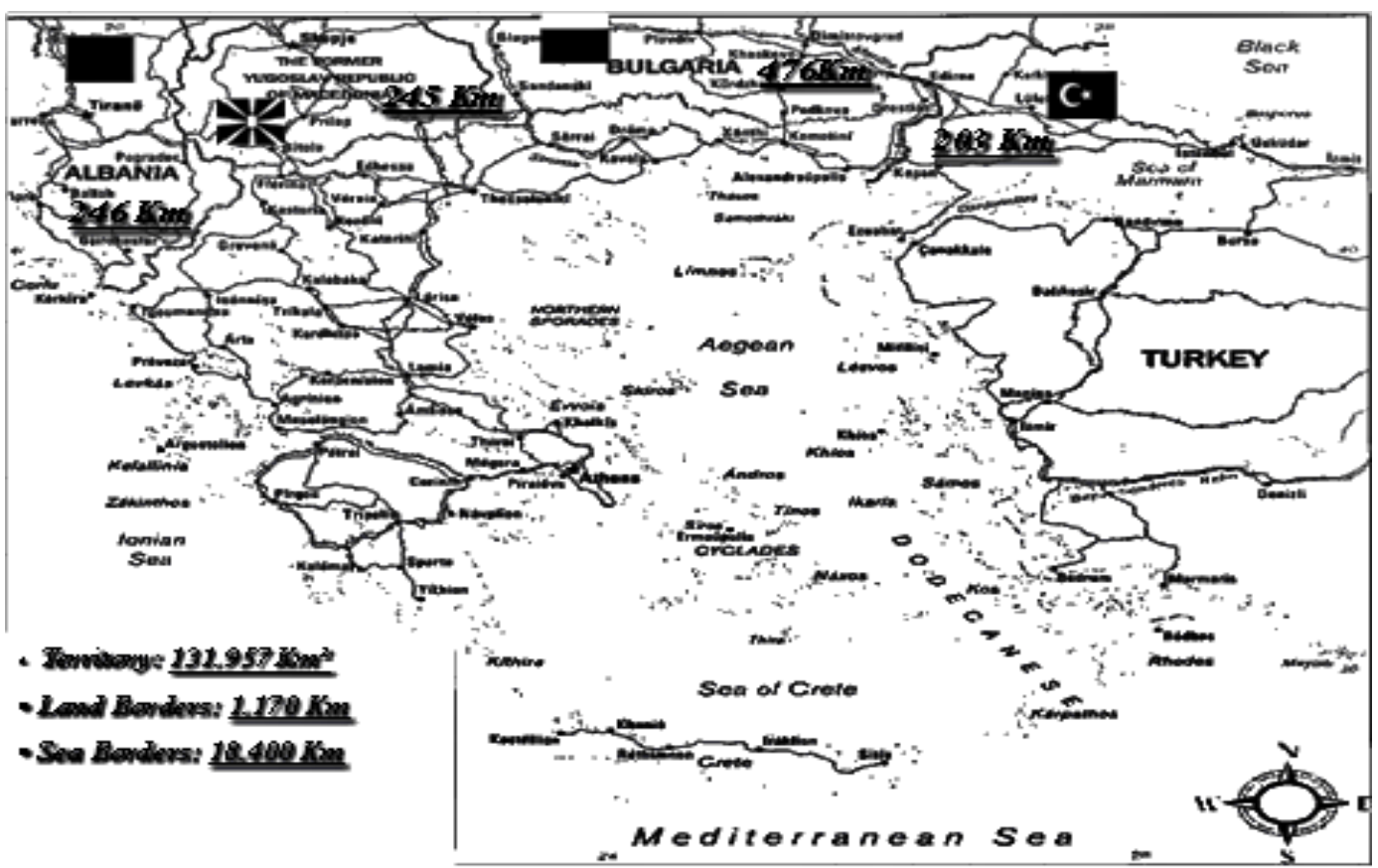

Figure 2. Land and Sea borders of Hellas

Source: Conference «ATHENA 09», Athens 10/2009.

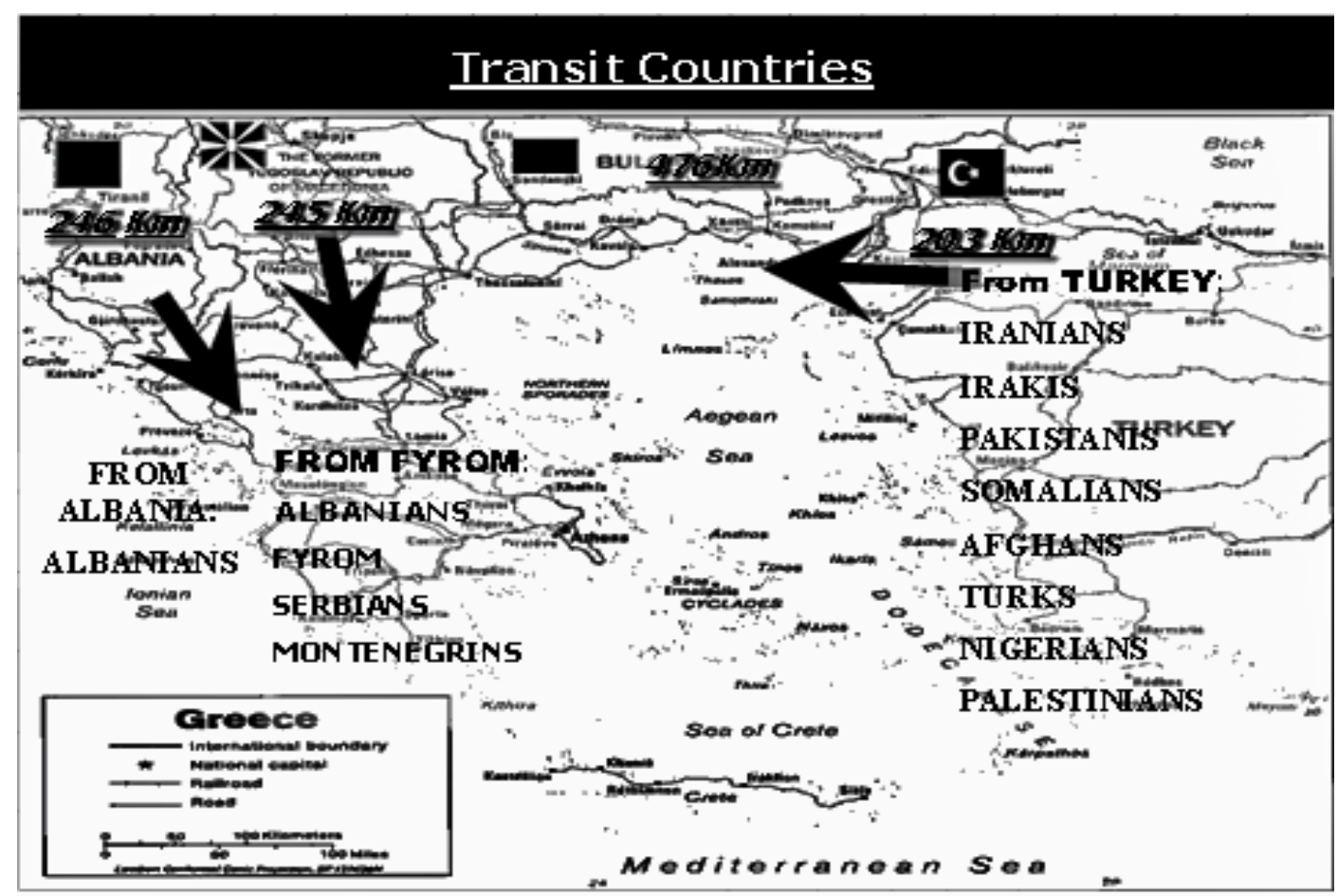

Figure 3. Transit countries

Source: Conference «ATHENA 09», Athens 10/2009. 


\section{FACILITATORS}

Arrested Facilitators
$2005: 799$
$2006: 994$
$2007: 1.421$
$2008: 2.211$

Eive Main Gitizenships for the ver 2008:

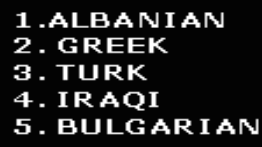

Figure 4. Facilitators

Source: Conference «ATHENA 09», Athens 10/2009.

ARRESTED ILLEGAL IMMIGRANTS IN THE E.U IN 2008

COUNTRY

1. GREECE

2. SPAIN

3. ITALY

5. PORTUGAL

6. UNITED KINGDOM

7. BELGIUM

B. SWEDEN

9. GERMANY

10. THE NETHERLANDS
ARRESTED. ILL IMMIGR.

146,337
100,694

85,488

82,763

28,637

28,489

27,307

20,918

9,818

8, 386
PER CENTAGE

$24.54 \%$

$16.88 \%$

$14.33 \%$

$13.88 \%$

$4.80 \%$

$4.77 \%$

$4.57 \%$

3.50\%

$1.64 \%$

$1.40 \%$

Figure 5. Arrested illegal Immigrants in the EU in 2008

Source: Conference «ATHENA 09», Athens 10/2009.

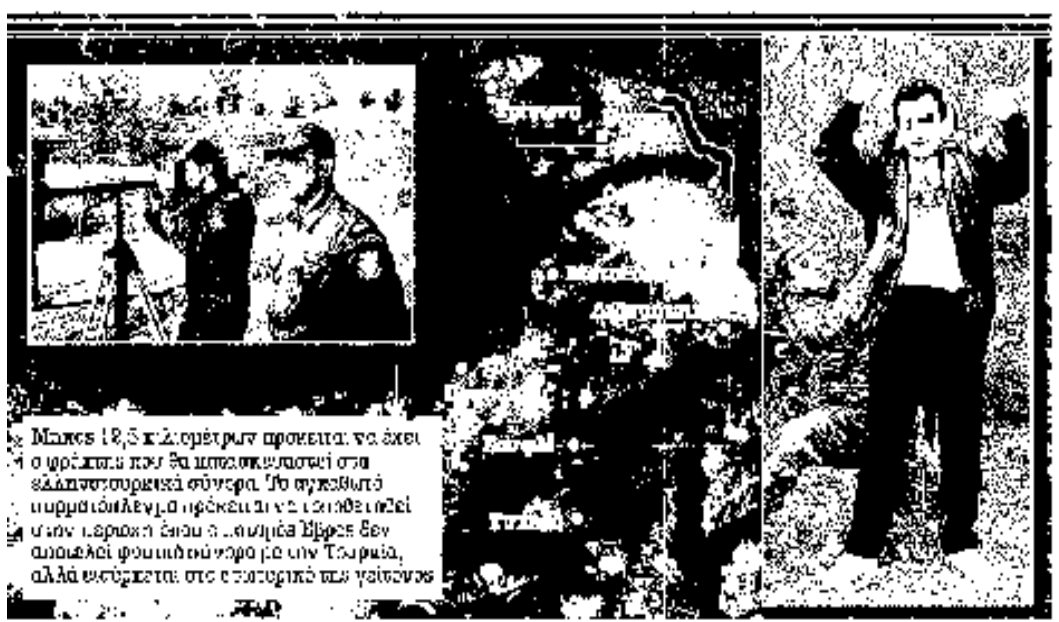

Figure 6. Fence in the area of Evros

Source: Newspaper «ETHNOS», 16/10/2011. 